\title{
Seasonal changes of testis volume and sperm quality in adult fallow deer (Dama dama) and their relationship to the antler cycle*
}

\author{
B. Gosch and K. Fischer \\ I. Zoological Institute of the University of Göttingen, Study Group of Comparative Endocrinology, \\ Berliner Strasse 28, D-3400 Göttingen, FRG
}

\begin{abstract}
Summary. Four adult male fallow deer were investigated for $1-4$ consecutive years to study the relationships between annual changes in testis volume, sperm quality and antler status. Testicular volume started to increase in July/August, peaked just before the rut, declined until December to $50 \%$ of maximum, persisted at this level up to February/March and reached minimal volume after antler casting in late April. There was no apparent age effect on the seasonality of testis size fluctuations. Velvet shedding and antler casting occurred at about $80 \%$ and $25 \%$, respectively, of maximal testis volume.

Spermatozoa had the same general appearance as those of related ruminants. Viable spermatozoa appeared between August and early May which corresponds almost exactly to the time when fallow deer are in hard antler. From September to March sperm quality would fulfil artificial insemination standards for cattle semen. In June and the first half of July 14 out of 15 ejaculates were devoid of any sperm cells. There were no indications of a secondary seasonal peak in values monitored.
\end{abstract}

Keywords: fallow deer; antler cycle; seasonality; electroejaculation

\section{Introduction}

There is much literature available on several aspects of the reproductive physiology of cervids. However, long-term studies dealing with individually marked male deer throughout all seasons and for several consecutive years are scarce and often incomplete.

In male fallow deer (Dama dama), most reports of the annual cycle of the reproductive system have been based on histological examinations (Chapman \& Chapman, 1970, 1975, 1979; Chaplin \& White, 1972; Kennaugh et al., 1977; Sterba \& Klusàk, 1984). Recently, Asher et al. (1987) monitored a group of bucks over a 13-month period to investigate seasonal changes in reproductive ability. Fischer $(1983,1984)$ succeeded in provoking late birth in fallow deer up to October. All these studies reveal that the potential fertile period of fallow deer is considerably longer than the rutting season. However, the investigations were partly of a preliminary nature and the findings were inconclusive, especially with regard to the onset and the cessation of spermatogenesis.

As changes in sperm quality have been proved in several mammals to be a good index for the functional condition of the reproductive system, we have investigated semen samples of individual fallow bucks throughout all seasons and for several consecutive years. This investigation should make it possible to determine more precisely the duration of the breeding season as well as the recommencement and the cessation of spermatogenic activity. These changes were also correlated with the seasonality of testis size and the antler cycle.

*Reprint requests to Prof. Dr K. Fischer. 


\section{Materials and Methods}

Experimental animals. In July 1982 the examination started with 2 bucks: Buck $I V$ was 2 years and Buck $G$ was 3 years old. Buck $G$ died in September 1983. In 1984 and 1985 the 3-year-old bucks $Z$ and $V$ were included, permitting study of 11 annual cycles up to mid-1987. The deer were housed near Göttingen, FRG $\left(51^{\circ} 32^{\prime} \mathrm{N}, 9^{\circ} 56^{\prime} \mathrm{E}\right)$, under outdoor conditions. They were fed with green fodder (summer) as well as protein pellets and hay (winter). Every 2-5 weeks the bucks were immobilized using 2-2.5 ml 'Hellabrunner Mixture' (Wiesner, 1975).

Testis volume. The length and breadth of both testes were measured with sliding calipers. Volume was calculated using the formula of a prolate spheroid: $\mathrm{V}=\frac{4}{3} \pi \mathrm{ab}^{2}$ ( $\mathrm{a}=$ longitudinal, $\mathrm{b}=$ transversal radius).

Semen collecting apparatus and collecting method. Semen was collected by electroejaculation using a bipolar rectal probe (Ball \& Furman, 1972). It was $2.8 \mathrm{~cm}$ in diameter, $30 \mathrm{~cm}$ in length and had 3 surface electrodes which were placed $0.7 \mathrm{~cm}$ equidistantly apart. The probe was inserted to its full length with the electrodes orientated ventrally. The stimulator produced sine-wave pulses of $50 \mathrm{~Hz}$ with a variable output of current intensity $(0-23 \mathrm{~V})$. A 5-ml tube fitted with a funnel served to collect the semen. This device was seated in an adjustable plastic flask, which served as a water bath $\left(39^{\circ} \mathrm{C}\right)$.

The stimulation regimen was a sequence of increasing electrical stimuli, each separated by a pause of about $3 \mathrm{sec}$. Peak voltage (max. $18 \mathrm{~V}$ ) was heightened with each stimulation, applied for 3-5 sec, and then rapidly diminished to zero. The number of stimuli was restricted to $\sim 15$ to minimize stress. Occasionally split ejaculates were obtained.

Semen appraisal. Immediately after collection an aliquant of the raw semen was diluted $(1: 20 \mathrm{v} / \mathrm{v})$ with physiological saline $(0.154 \mathrm{M}-\mathrm{NaCl})$ and preserved at $39^{\circ} \mathrm{C}$ whilst the remaining portion was stored at $-20^{\circ} \mathrm{C}$. Colour and volume (to the nearest $0.1 \mathrm{ml}$ ) were registered. Consistency was graded into 4 categories: watery, milky, creamy and viscous. Sperm concentration was determined using standard haemocytometer methods. Calculations were made of the total numbers of spermatozoa per ejaculate.

Motility estimations were made within $2 \mathrm{~h}$ after collection under phase-contrast optics $(\times 250)$ at $39^{\circ} \mathrm{C}$. The examination was carried out with reference to Freund (1968). The percentage of motile spermatozoa was estimated to the nearest $10 \%$ and the grade of motility, as expressed by the majority of the sperm cells, was rated 0 to 4: $0=$ motionless, $1=$ twisting without any forward motion, $2=$ weak, $3=$ middle, $4=$ powerful forward progression.

Air-dried smears were Farelly-stained (ingredients: aniline blue and crystal violet (Paufler, 1974)) and examined for pleiomorphic forms. With each smear 100 spermatozoa were enumerated (oil-immersion $\times 1000$ ), and abnormalities were expressed in percentages. The ratio of spermatozoa to other cells was also evaluated.

Statistical analysis. Because of the unequal number of investigated annual cycles (1-5), the data for Fig. 1 were converted by second-order statistics (Batschelet, 1981) and expressed as monthly mean \pm s.d. values. Statistical analysis of ejaculate volumes was done by $t$ test.

\section{Results}

\section{Testis volume and antler cycle}

Minimal testis volume was recorded from April to June and maximal development in September and October (Fig. la). Subsequently, the volume dropped to almost $50 \%$ by December and remained at this level until February/March. Velvet shedding took place when testicular volume had reached $\sim 80 \%$ of maximal volume and casting occurred when the volume was about $25 \%$ of maximum. Figure 2(a) shows the annual changes in testicular volume for Bucks $I V, Z$ and $V$ over 2-3 consecutive years.

\section{Electroejaculation}

Electroejaculation was successful in 157 of 158 attempts. Usually 3-5 stimuli were required to initiate ejaculation. Extrusion of the penis was achieved in most cases and occurred during the early stages of stimulation. No injury of any kind was observed.

\section{Semen evaluation}

General appearance. From April to August semen specimens were watery and for the most part colourless. Occasionally, some of the specimens were light yellow in colour. During the remainder 


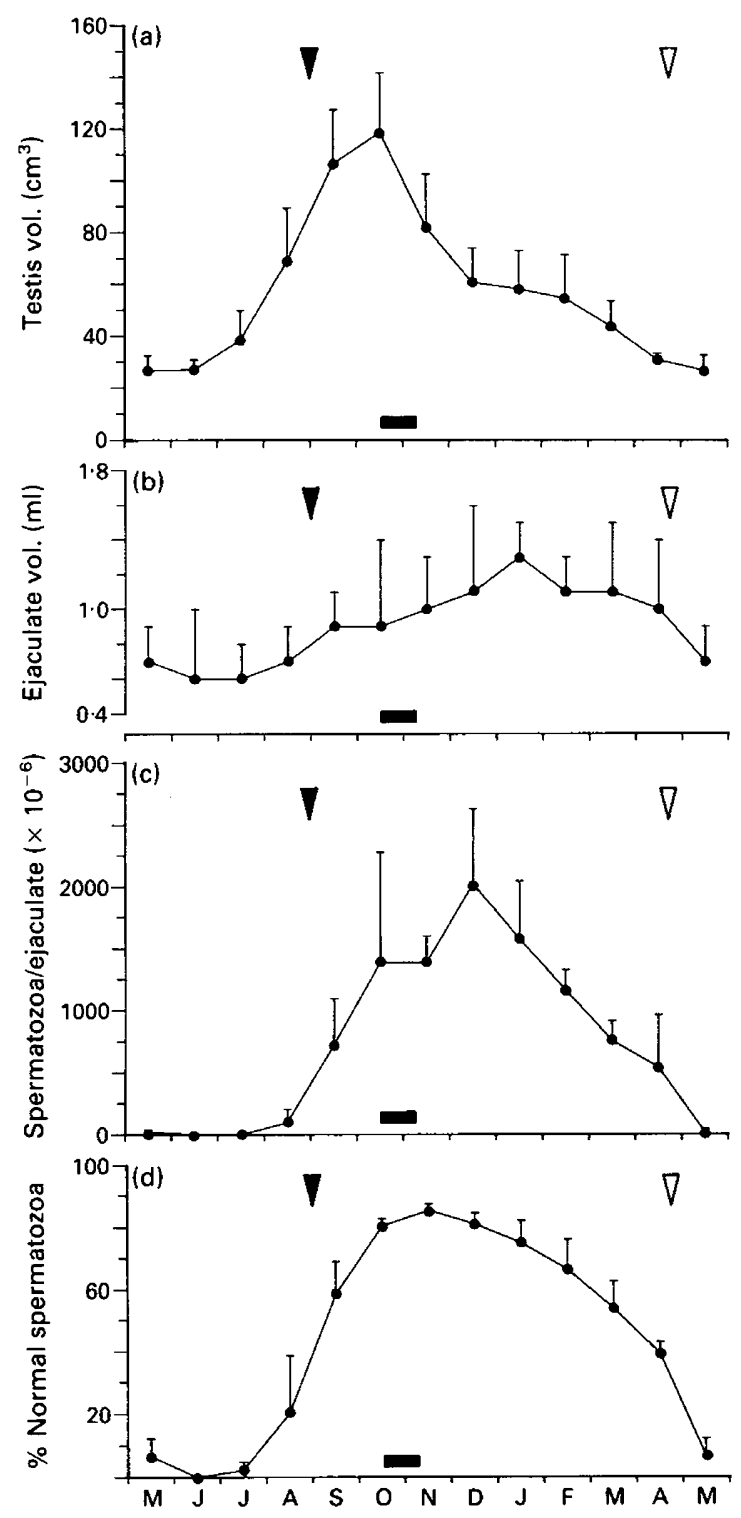

Fig. 1. General annual profiles of (a) testicular volume, (b) ejaculate volume, (c) sperm density, and (d) percentage of normal spermatozoa. Values are monthly means \pm s.d. for 4 bucks. Bars = rutting periods; solid arrowheads = velvet shedding; open arrowheads $=$ antler casting.

of the year the first portion was mostly white, but sometimes amber in colour, of a milky to creamy consistency and normally rich in spermatozoa. In September and again from mid-December/ mid-January until March the sperm portion was usually followed by a more watery one, whereas from October to mid-December/mid-January the later portion was a viscid bright yellow azoospermic fluid. There were some individual variations among the bucks and between successive collections. Sometimes the viscid fluid preceded or accompanied the sperm portion, and sometimes a buck failed to ejaculate one of the components. During the rutting season, semen samples often had a changed colour, and were brown and even occasionally black. 

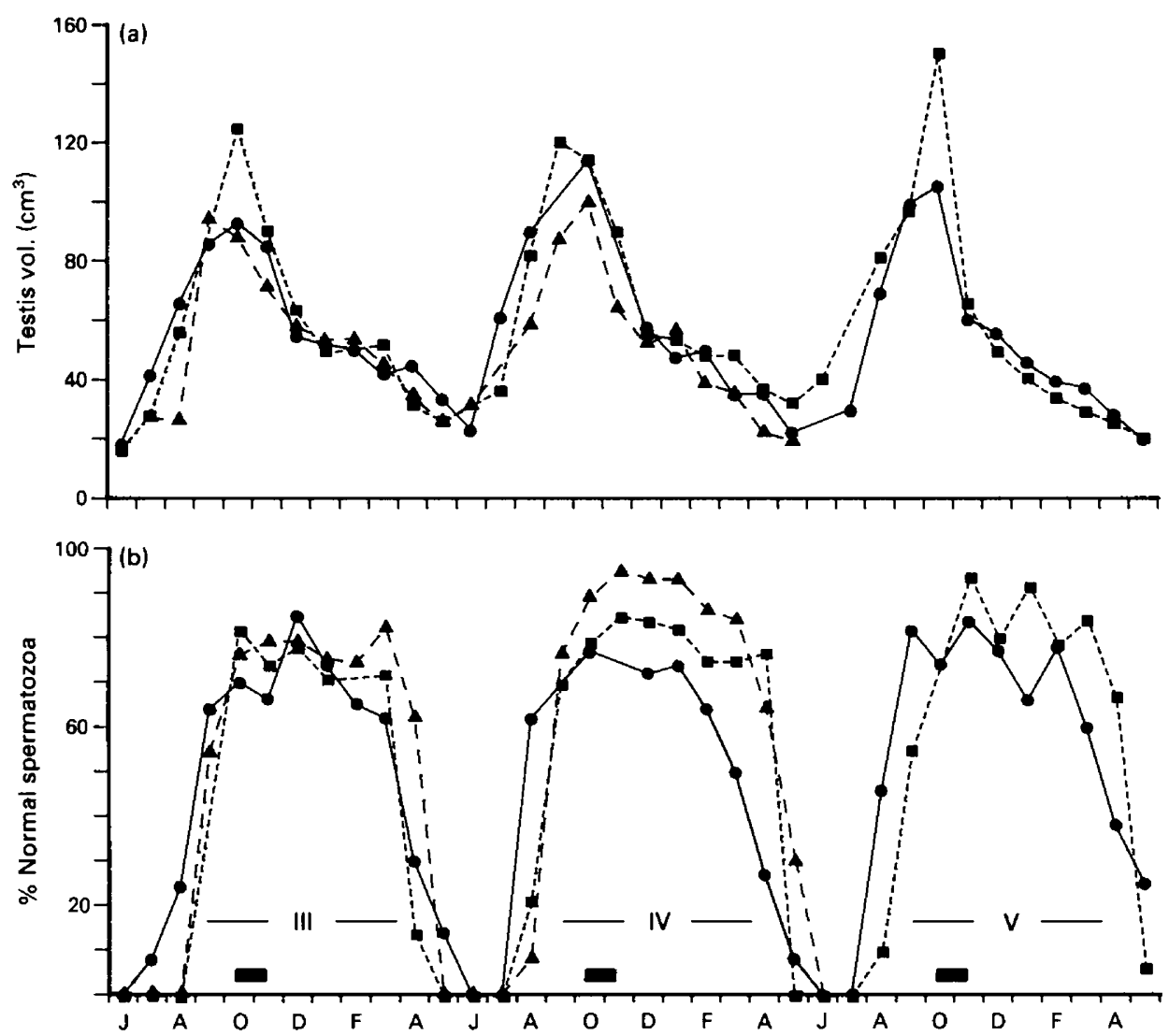

Fig. 2. Individual annual profiles of (a) testicular volume, (b) percentage of normal spermatozoa in Bucks $I V(\mathbf{O}), V(\mathbf{\Delta})$ and $Z(\mathbf{\square})$ over 2-3 consecutive years. Bars = rutting period; Roman numerals $=$ age of bucks.

Volume. Volumes of semen varied from a few drops up to a maximum of $2.5 \mathrm{ml}$ (Fig. 1b). An extraordinarily copious specimen of $4 \mathrm{ml}$ was excluded from all calculations because of probable contamination by urine. In general, ejaculates obtained during antler growth (May-August) (mean \pm s.d. $=0.7 \pm 0.4 \mathrm{ml} ; n=47$ ) were significantly smaller $(P<0.0001)$ than specimens collected while the animals were in hard antler (September-April) $(1.1 \pm 0.4 \mathrm{ml} ; n=109)$.

Sperm density. In June and the first part of July all ejaculates $(n=15)$ except one were devoid of any spermatozoa (Fig. 1c). The exception was on 3 June when a specimen of only $1 \times 10^{6}$ spermatozoa was emitted. From the second half of July up to the first part of May all ejaculates contained spermatozoa in various numbers. Between October and February, inclusive, monthly means were $>1000 \times 10^{6}$ spermatozoa/ejaculate, although the densities varied widely from buck to buck and from one collection to another (range: $200 \times 10^{6}-4000 \times 10^{6}$ spermatozoa/ejaculate).

Motility estimation. In general, high ratings of motility ( $\% \geq 60$, grades $\geq 3$ ) were obtained from September to mid-October and again from December to mid-April (Table 1).

Morphological findings. Figure 2(b) shows the individual course of the percentage of normal spermatozoa for 3 animals over 2-3 consecutive years. The general seasonal profile is shown in Fig. 1(d). From September until March mean values remained at $\geq 60 \%$.

Normal and abnormal spermatozoa are presented in Figs 3 and 4. Deformities varied from season to season. From October to March deformities were equally common amongst heads and 


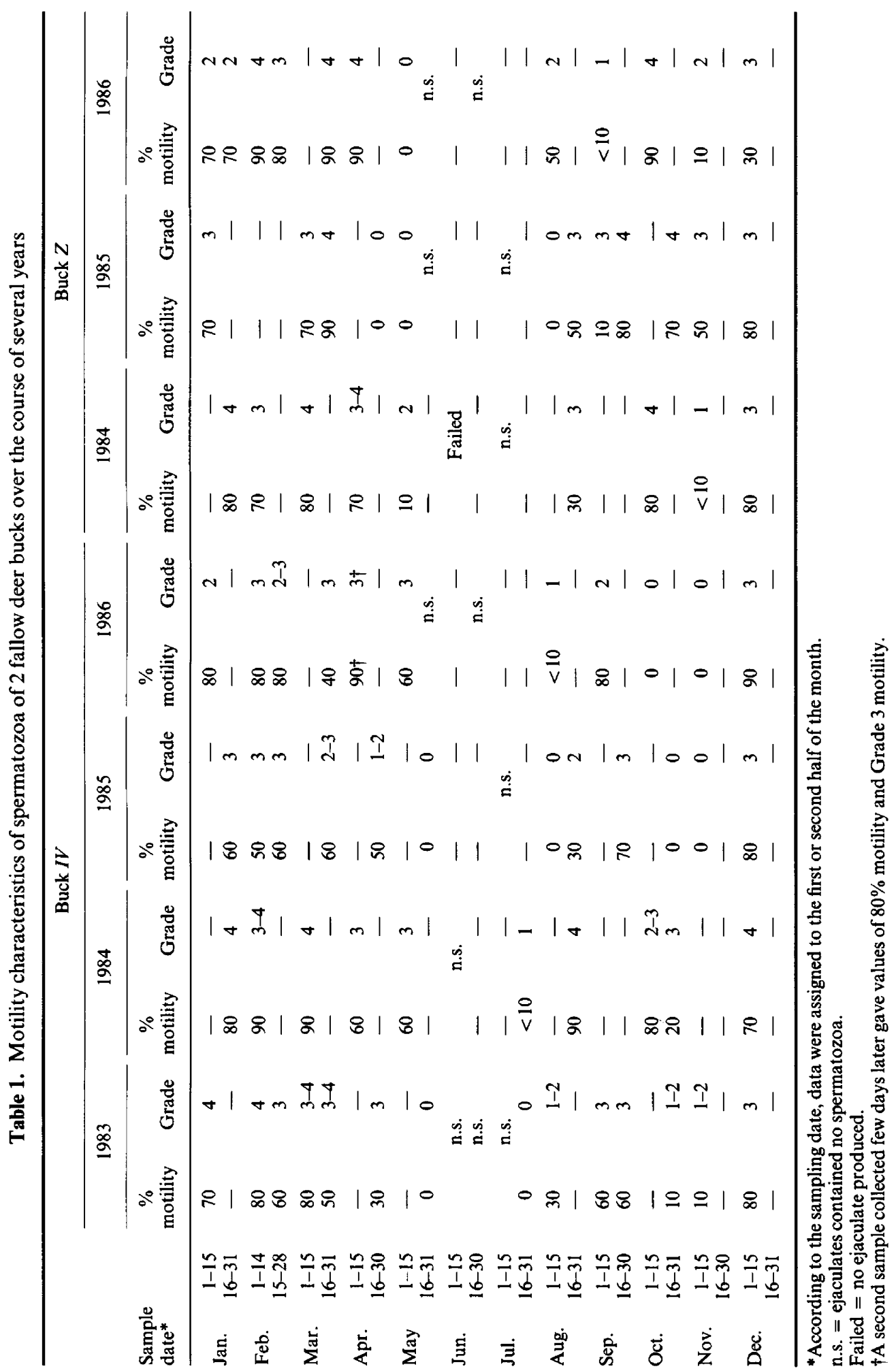


tails. At the beginning and at the end of the sperm-rich period, sperm cells with droplets and large cytoplasmic remnants were predominant in the counts. Large numbers of microcephalic forms were typical at the very beginning of the fertile period (Fig. 3: B2, B4).

Presence of other cells. From September up to late March $>99 \%$ of the cells were spermatozoa. Specimens sampled during the ensuing months of April to early August contained high quantities of epithelial cells, aborted germinal material, and diverse unidentifiable cellular debris. Sometimes cells similar to the so-called medusa formations (Blom, 1944, 1947) were observed (Fig. 3: A1, A2; Fig. 4: D1).

\section{Discussion}

Chronobiologists state that an annual rhythm can only be defined as such when the same changes recur in each of several consecutive years with the same frequency and phase-relationship (Aschoff, 1955). To fulfil these requirements, the present report provides results from observations on individual fallow deer bucks over several years.

The general testicular cycle is similar to those reported by other authors for fallow deer (Chapman \& Chapman, 1970, 1975; Chaplin \& White, 1972; Asher et al., 1987) and in accordance to observations on other deer species (see Lincoln, 1985): maximum size occurs just before rut commences and minimum size was recorded when antlers started to regrow. In addition, our measurements show that, after the rutting season, testis volume remains at about $50 \%$ of maximum from December until February/March before it finally declines to the annual minimum. Obviously, this level provides conditions for sufficient testicular activity to ensure fertile matings at least up to February/March (Chapman \& Chapman, 1975; Fischer, 1983, 1984). A corresponding level of testis size can be calculated from data presented by Asher et al. (1987) for fallow bucks and by Haigh et al. (1985) for wapiti (Cervus elaphus nelsoni).

In fallow deer, shedding of the velvet regularly occurred when gonadal volume had reached $\sim 80 \%$ of maximum. Casting, on the other hand, was recorded when testis volume had dropped to about $25 \%$ of the annual maximum. This particular relationship persisted even when fallow bucks were subjected to artificially shortened annual photoperiodic cycles (Gosch \& Fischer, 1986). In our view, these results show that the distinct relationship between testis volume and antler casting/velvet shedding is not only associated with an increase and a decrease of the activity of the reproductive system, but also reflects the 2 threshold values.

The testes of yearlings are significantly smaller than those of adults, but there are no obvious indications of a progressive increase in peak testicular volume between adults of different age classes (Chaplin \& White, 1972; Gosch \& Fischer, 1984). However, Chapman \& Chapman (1975) and Lincoln (1981) postulated such an age-related increase in peak testicular volume for fallow deer bucks and red deer stags (Cervus elaphus).

Electroejaculation was first attempted on fallow deer by Seager et al. (1978), but the ejaculates were azoospermic for unexplained reasons. Asher et al. (1987) described some characteristics of spermatozoa from electroejaculated fallow deer bucks, but, due to infrequent sampling and possibly incomplete stimulation, their findings differ in part from our results. The average semen volume collected in the current study was considerably higher, and, unlike Asher et al. (1987), we were able to demonstrate a seasonal cycle in mean ejaculate volume with maximal volumes during the time the deer were in hard antler. The viability of the semen obtained between January and March has been verified by the birth of fawns after artificial insemination with deep-frozen semen pellets (B. Gosch, S. Heiden, W. Wemheuer, K. Fischer, unpublished data).

From September to March the general semen quality would satisfy commercial artificial insemination standards for cattle (i.e. density $\geq 800 \times 10^{6}$ spermatozoa/ejaculate, $\%$ of normal spermatozoa $\geq 60, \%$ of motile spermatozoa $\geq 60$, grade of motility $\geq 3$ ). Fallow bucks are apparently capable of breeding from late August to April, corresponding to the time they are in 

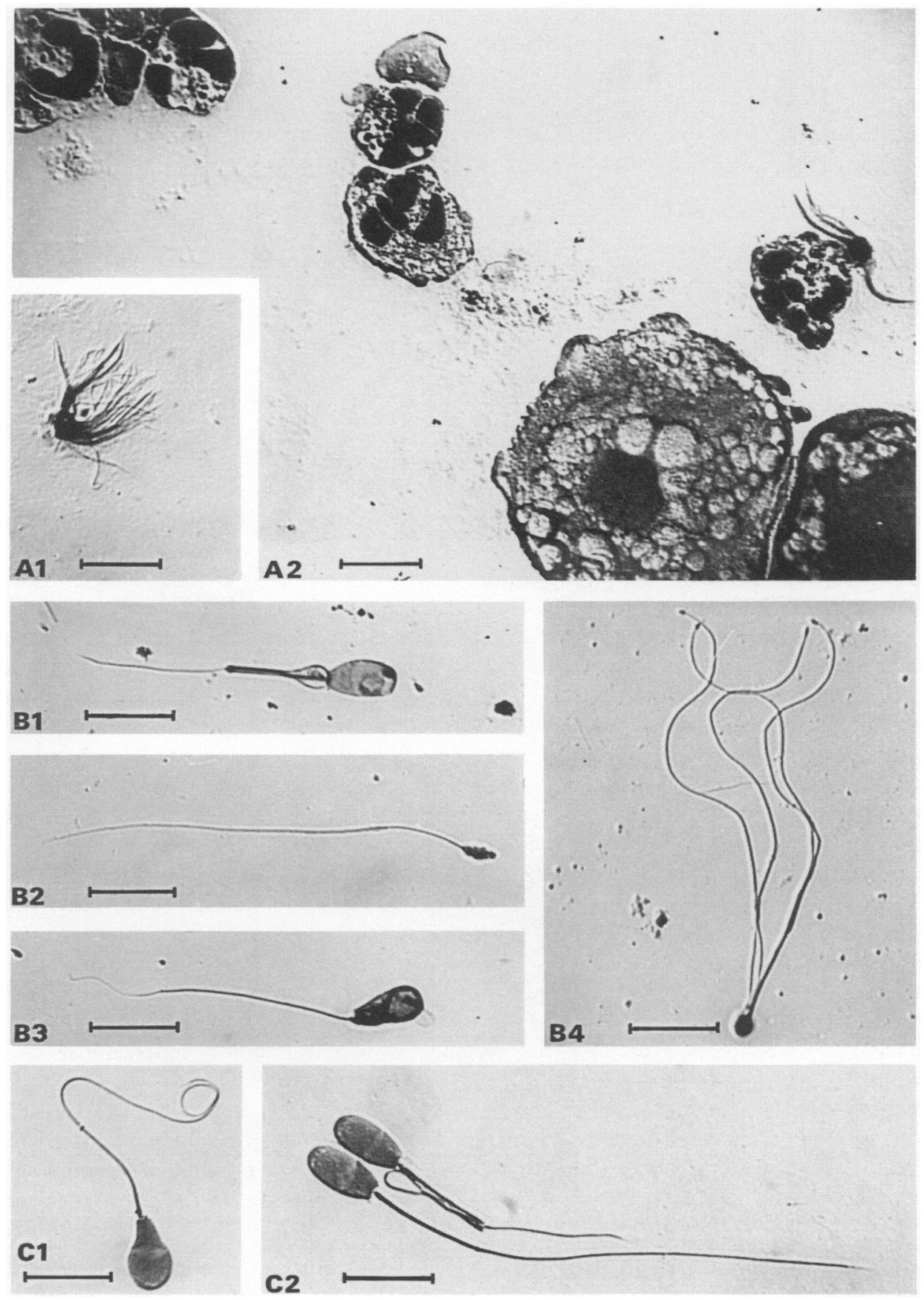

Fig. 3. Differential interference-contrast micrographs of Farelly-stained spermatozoa. Bars = $10 \mu \mathrm{m}$. A1, A2: specimen of 21 June: medusoids and cellular debris, no spermatozoa; B1-B4: specimen of 5 August: abnormal spermatozoa, microcephalics; C1, C2: specimen of 28 August: 1 normal and 2 abnormal spermatozoa. 

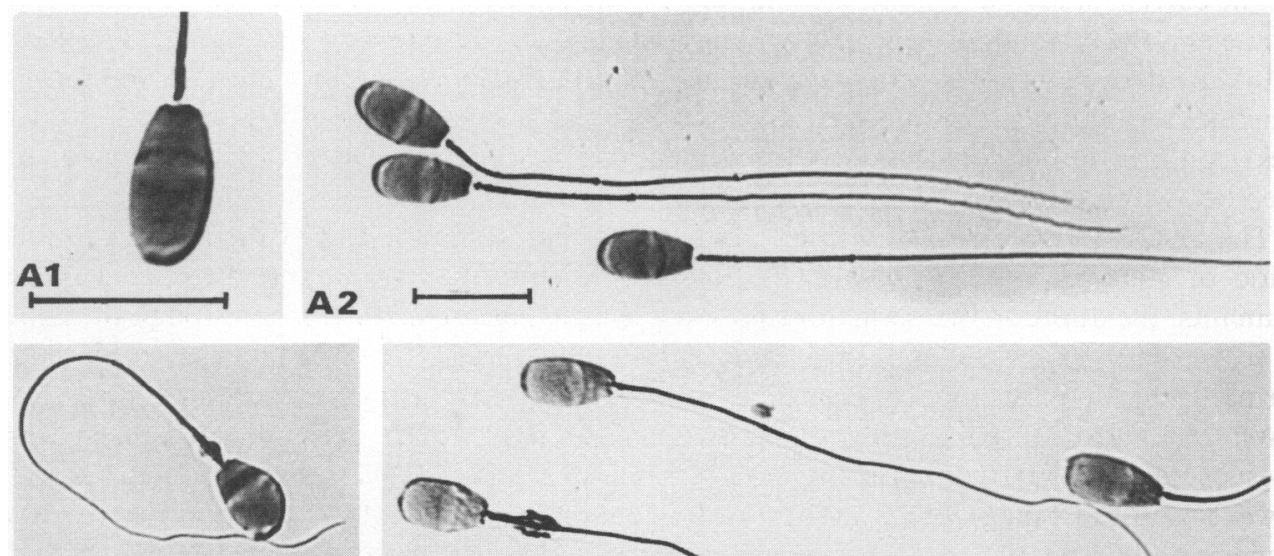

B1
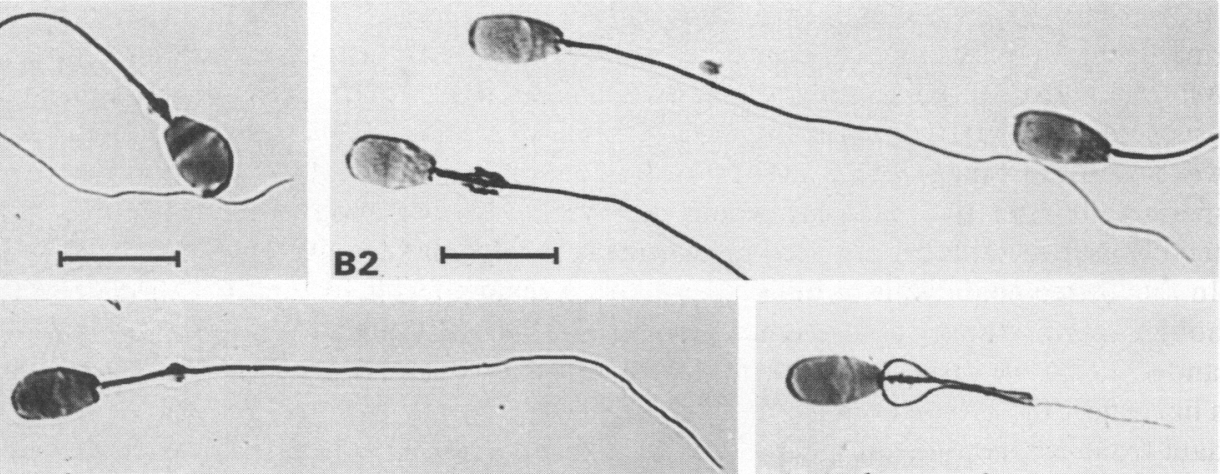

B3

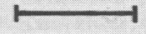

B4

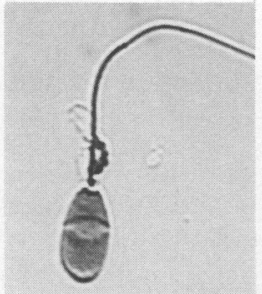

C1
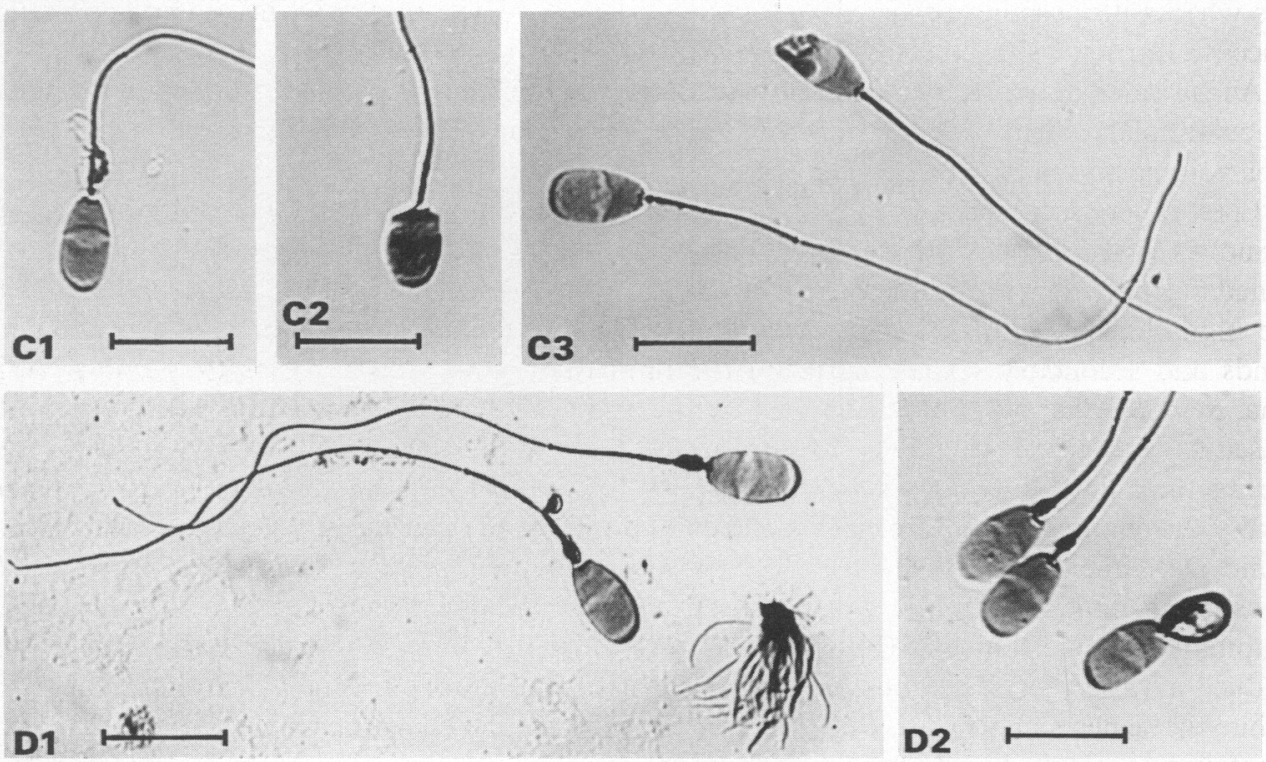

Fig. 4. Differential interference-contrast micrographs of Farelly-stained spermatozoa. Bars = $10 \mu \mathrm{m}$. A1, A2: specimen of 4 February: normal spermatozoa, typical for fertile period; B1-B4: specimen of 18 March: 2 normal and different abnormal spermatozoa; C1-C3: specimen of 14 April: 1 normal and different abnormal spermatozoa; D1, D2: specimen of 3 May: medusoid cell and abnormal spermatozoa with cytoplasmic droplets.

hard antler. Indeed, Asher \& Macmillan (1986) reported early conception on 23 February on the Ruakura Station, New Zealand, and it is well known that fallow deer actually mate as late as February or March (Chapman \& Chapman, 1975; Fischer, 1983, 1984). 
The current study has determined that there is an almost complete annual lack of spermatozoa in June and the first half of July. This finding is in good accordance with Lincoln $(1981,1985)$ who postulated that, in seasonal mammals, spermatogenesis totally ceases for a time, and no germ cells complete maturation when the size of the gonads drops below $30 \%$ of maximum. Fallow deer bucks conform to this rule as semen samples became azoospermic shortly after testis volume had fallen below this limit.

The first small numbers of normal spermatozoa, indicating the end of the fallow deer buck's period of gonadal quiescence, could be found in the first half of August. In related domestic ruminants, the duration of spermatogenesis and the passage of spermatozoa through the epididymis requires 51-60 days (White, 1974; Gomes, 1978). We therefore believe the recommencement of spermatogenic activity in fallow deer to be in June/July. From histological examinations, Chaplin \& White (1972) deduced considerable individual variations in the seasonal onset of spermatogenesis, and they reported that the renewed spermatogenesis took place between March and July. However, our data suggest that inter-individual and intra-individual variations in the appearance of sperm cells after the quiescent period occurred only over about 1 month (Table 1) and no evidence was detectable for any recommencement of testicular activity from March to early June.

In the ligated epididymis of bulls, spermatozoa remain fertile for up to 60 days (White, 1974). Although sperm storage is a distinct physiological characteristic of the epididymis (Glover \& Nicander, 1971), we suspect that sperm cells obtained at the end of the fertile period are not stored cells but reflect the actual, even if very low, activity level of the deer's testes. Our view is supported by data from observations on fallow deer bucks subjected to artificially shortened annual photoperiodic cycles: under these experimental conditions there was a sudden disappearance of sperm cells when antler casting occurred and, within a few days, sperm density decreased from average concentrations $>1500 \times 10^{6}$ to nearly zero (Gosch \& Fischer, 1986).

As indicated above, testicular activity recommenced in June/July. This is about 2 months before testicular enlargement becomes obvious. There is a similar delay of about 2 months between peak testis volume and maximal sperm density.

Like other deer species, fallow deer bucks exhibit marked annual profiles of androgen hormones, with peak values just before the onset of the rut and declining concentrations immediately after the rutting season (Fischer, 1982; Rolf \& Fischer, 1986, 1987; Asher et al., 1987). The high concentrations of androgens may well cause the rapid development of accessory sex glands and secondary sexual characteristics until rut begins. This involves the seminal vesicles (Chapman \& Chapman, 1979) as well as the preputial glands (Kennaugh et al., 1977). As a consequence of their sensitivity to androgens, these glands regress immediately after the rut. During their limited period of full activity, the secretions of these androgen-dependent glands modify the composition of the ejaculates and may alter some sperm characteristics. From October to mid-December/mid-January, therefore, the ejaculates are often mixed with a viscid bright yellow azoospermic fluid apparently originating from the vesicular glands (Hinz, 1930; Chapman \& Chapman, 1979). From mid-October until November the prepuce is everted and related glands produce a variety of sebaceous and sweat secretions (Kennaugh et al., 1977) which frequently pollute the semen samples. So, within a few minutes these ejaculates change to a brown colour, and sometimes to black. In addition, the preputial secretions probably weaken the sperm cells and consequently motility values are greatly reduced (Table 1). For these reasons, it seems advisable to take semen for artificial insemination between December and March.

Fallow deer spermatozoa do not differ greatly in size, shape and aberrations from those of related domestic mammals. Similar observations have been reported for moose (Alces alces) (Andersen, 1973), wapiti (Haigh et al., 1984, 1985), white-tailed deer (Odocoileus hemionus columbianus) (Bierschwal et al., 1970), reindeer (Rangifer tarandus) (Dott \& Utsi, 1971) and sika deer (Cervus nippon) (Wislocki, 1949).

Reports of the so-called medusa cells are very limited and have not been published for deer species up to the present (Fig. 3: A1, A2; Fig. 4: D1). In fallow deer bucks they were found mainly 
during the period of gonadal quiescence. Their appearance indicates the overall decline in testicular activity. Medusa formations are detached fragments of the ciliated border of the ductuli efferentes (Blom, 1944, 1947; Zemjanis, 1969). They are known from bulls and stallions suffering from severe orchitis or testicular degeneration.

All the results presented in this paper clearly show an annual monophasic periodicity. There are no indications at all of any secondary peaks of values as has been discussed by West \& Nordan (1976) and Haigh et al. (1984) for other deer species.

We thank Dr W. Wemheuer and S. Heiden (Department of Veterinary Medicine, University of Göttingen, FRG) for help and advice during the study, and the team of Prof. Dr K. Fischer for assistance in animal management and semen sampling. The work was supported by the Niedersächsisches Ministerium für Ernährung, Landwirtschaft und Forsten, Hannover, FRG (grant No. 113/477.301), as well as by the Niedersächsische Jägerschaft.

The work is submitted by B.G. in partial fulfilment of the requirements for the degree of Dr. rer. nat.

\section{References}

Andersen, K. (1973) Morphological and ultrastructural studies of moose spermatozoa. Acta vet. scand. 14, $81-91$.

Aschoff, J. (1955) Jahresperiodik der Fortpflanzung bei Warmblütern. Studium Generale 12, 742-776.

Asher, G.W. \& Macmillan, K.L. (1986) Induction of oestrus and ovulation in anoestrous fallow deer (Dama dama) by using progesterone and GnRH treatment. J. Reprod. Fert. 78, 693697.

Asher, G.W., Day, A.M. \& Barrell, G.K. (1987) Annual cycle of liveweight and reproductive changes of farmed male fallow deer (Dama dama) and the effect of daily oral administration of melatonin in summer on the attainment of seasonal fertility. J. Reprod. Fert. 79, 353-362.

Ball, L. \& Furman, J.W. (1972) Electroejaculation of the bull. Bov. Practitioner 7, 46-48.

Batschelet, E. (1981) Circular Statistics in Biology. Academic Press, London.

Bierschwal, C.J., Mather, E.C., Martin, C.E., Murphy, D.A. \& Korschgen, L.J. (1970) Some characteristics of deer semen collected by electroejaculation. $J$. Am. vet. med. Assoc. 157, 627-632.

Blom, E. (1944) On the occurrence in bull sperm of certain $>>$ medusa formations $<<$ derived from the epithelium of the efferent ducts of the testis. Acta path. microbiol. scand. 21, 713-720.

Blom, E. (1947) Om Medusadannelser (afstødte Fimrebræmmer) i Tyre-og Hingstesperma og disses diagnostiske Betydning. Skand. Vet. Tidskr. 37, 257-265.

Chaplin, R.E. \& White, R.W.G. (1972) The influence of age and season on the activity of the testis and epididymides of the fallow deer, Dama dama. J. Reprod. Fert. 30, 361-369.

Chapman, D.I. \& Chapman, N.G. (1970) Preliminary observations on the reproductive cycle of the male fallow deer (Dama dama L.). J. Reprod. Fert. 21, 1-8.

Chapman, D.I. \& Chapman, N.G. (1975) Fallow Deer: their History, Distribution and Biology. Terence Dalton Ltd, Lavenham.
Chapman, N.G. \& Chapman, D.I. (1979) Seasonal changes in the male accessory glands of reproduction in adult fallow deer (Dama dama). J. Zool., Lond. 189, 259-274.

Dott, H.M. \& Utsi, M.N.P. (1971) The collection and examination of semen of the reindeer (Rangifer tarandus). J. Zool., Lond. 164, 419-424.

Fischer, K. (1982) Rut, breeding season, conception, birth, and plasma testosterone levels in young fallow deer (Dama dama L.). Acta endocr., Copenh. 99, Suppl. 246, 14, Abstr.

Fischer, K. (1983) Untersuchungen zur Fortpflanzungsfähigkeit von jungem weiblichem und männlichem Damwild (Dama dama L.). Z. Jagdwiss. 29, 137-142.

Fischer, K. (1984) Provozierte Spätgeburten 1983. Addendum zu: Untersuchungen zur Fortpflanzungsfähigkeit von jungem weiblichem und männlichem Damwild (Dama dama L.). Z. Jagdwiss. 30, 124-126.

Freund, M. (1968) Semen analysis. In Progress in Fertility, pp. 593-627. Eds S. J. Behrman \& R. W. Kistner. J. \& A. Churchill Ltd, London.

Glover, T.D. \& Nicander, L. (1971) Some aspects of structure and function in the mammalian epididymis. J. Reprod. Fert., Suppl. 13, 39-50.

Gomes, W.R. (1978) Formation, migration, maturation, and ejaculation of spermatozoa. In Physiology of Reproduction and Artificial Insemination of Cattle, pp. 211-245. Eds G. W. Salisbury, N. L. VanDemark \& J. R. Lodge. Freeman and Company, San Francisco.

Gosch, B. \& Fischer, K. (1984) Spermauntersuchungen beim Damhirsch (Dama dama L.) verschiedener Altersstufen im Jahresgang. In Dtsch. Ges. Säugetierkunde, 58. Hauptversammlung, pp. 14-15, Abstr. Ed. H.-J. Kuhn. Parey, Hamburg.

Gosch, B. \& Fischer, K. (1986) Saisonal bedingte Änderungen der Gonadenfunktion adulter Damhirsche (Dama dama L.) bei normaler und künstlich beschleunigter Photoperiode. In Dtsch. Ges. Säugetierkunde, 60. Hauptversammlung,pp. 22-23, Abstr. Ed. F. Dieterlen. Parey, Hamburg.

Haigh, J.C., Cates, W.F., Glover, G.J. \& Rawlings, N.C. 
(1984) Relationships between seasonal changes in serum testosterone concentrations, scrotal circumference and sperm morphology of male wapiti (Cervus elaphus). J. Reprod. Fert. 70, 413-418.

Haigh, J.C., Barth, A.D., Cates, W.F. \& Glover, G.J. (1985) Electro-ejaculation and semen evaluation of wapiti. In Biology of Deer Production, pp. 197-203. Eds P. F. Fennessy \& K. R. Drew. Roy. Soc. NZ, Bull. 22, Wellington.

Hinz, K. (1930) Anatomische und histologische Untersuchungen des Hodens, der Samenleitung und des Beckenstücks der Harnröhre mit den accessorischen Geschlechtsdrüsen vom Damhirsch in der Brunftzeit. Inaug. Diss. Tierärztl. Hochschule, Berlin.

Kennaugh, J.H., Chapman, D.I. \& Chapman, N.G. (1977) Seasonal changes in the prepuce of adult fallow deer (Dama dama) and its probable function as a scent organ. J. Zool., Lond. 183, 301-310.

Lincoln, G.A. (1981) Seasonal aspects of testicular function. In The Testis, pp. 255-302. Eds H. Burger \& D. de Kretser. Raven Press, New York.

Lincoln, G.A. (1985) Seasonal breeding in deer. In Biology of Deer Production, pp. 165-179. Eds K. Drew \& P. Fennessy. Roy. Soc. NZ, Bull. 22, Wellington.

Paufler, S.K. (1974) Die künstliche Besamung beim Rind. In Künstliche Besamung und Eitransplantation bei Tier und Mensch, pp. 48-80. Eds S. K. Paufler, H. Bader, A. Bonfert, R. H. Foote, S. Salamon \& H. W. Vasterling. M. \& H. Schaper, Hannover.

Rolf, H.J. \& Fischer, K. (1986) Jahresperiodische Schwankungen der Testosteron und 5- $\alpha$-DHTKonzentration im Blut von adulten männlichen Damhirschen (Dama dama L.). In Dtsch. Ges. Säuge- tierkunde, 60. Hauptversammlung, pp. 61-62, Abstr. Ed. F. Dieterlen. Parey, Hamburg.

Rolf, H.J. \& Fischer, K. (1987) Annual periodicity of blood testosterone and 5- $\alpha$-DHT levels in the adult male fallow deer (Dama dama L.). Acta endocr., Copenh. 114, Suppl. 283, 178, Abstr.

Seager, S., Wildt, D. \& Platz, C. (1978) Artificial breeding of non-primates. Symp. zool. Soc. Lond. 43, $207-218$.

Sterba, O. \& Klusàk, K. (1984) Reproductive biology of fallow deer, Dama dama. Acta Sci. Nat., Brno 18, $1-46$.

West, N.O. \& Nordan, H.C. (1976) Hormonal regulation of reproduction and the antler cycle in the male Columbian black-tailed deer (Odocoileus hemionus columbianus). Part I. Seasonal changes in the histology of the reproductive organs, serum testosterone, sperm production, and the antler cycle. Can. J. Zool. 54, 1617-1636.

White, I.G. (1974) Mammalian semen. In Reproduction in Farm Animals, 3rd edn, pp. 101-122. Ed. E. S. E. Hafez. Lea \& Febiger, Philadelphia.

Wiesner, H. (1975) Zur Neuroleptanalgesie bei Zootieren und Gatterwild unter Anwendung des TelinjectSystems. Kleintierpraxis 20, 18-24.

Wislocki, G.B. (1949) Seasonal changes in the testes, epididymis and seminal vesicles of deer investigated by histochemical methods. Endocrinology 44, $167-122$.

Zemjanis, R. (1969) Semen examination. In Veterinary Clinical Pathology, pp. 497-510. Eds W. Medway, J. E. Prier \& J. S. Wilkinson. Williams \& Wilkins Co., Baltimore.

Received 4 February 1988 